\title{
Akomodasi Komunikasi pada Mahasiswa Beda Budaya di Kota Kupang
}

\author{
Petrus Ana Andung ${ }^{1}$, Ferly Tanggu Hana ${ }^{2}$, Antonia Bara Benge Tani ${ }^{3}$ \\ ${ }^{1,2,3}$ Universitas Nusa Cendana, Kupang, Indonesia
}

\begin{abstract}
ABSTRAK
Wawasan dan pemahaman multikultur belum mendapat perhatian serius dalam pendidikan tinggi. Bahkan, ketika mahasiswa baru memasuki pendidikan tinggi mereka tidak mendapat pelatihan khusus mengenai pengetahuan multikultur. Karena itu berbagai hasil penelitian baik di Indonesia maupun luar negeri memberikan data bahwa mahasiswa-mahasiswa luar daerah maupun asing cenderung mengalami berbagai kendala dalam hal adaptasi budaya. Karena itu, pilihan melakukan akomodasi komunikasi menjadi salah satu jawaban guna mengatasi kesenjangan komunikasi antar budaya. Salah satu kelompok mahasiswa di Universitas Nusa Cendana yang secara konsisten melakukan tindakan akomodasi komunikasi adalah mahasiswa etnis Manggarai. Karena itu penelitian ini dilakukan untuk menganalisis pengalaman akomodasi komunikasi mahasiswa etnis Manggarai dengan mahasiswa tuan rumah di Universitas Nusa Cendana, dan memetakan pemaknaan mahasiswa Manggarai sebagai mahasiswa perantau di Kota Kupang. Guna membantu menjelaskan hasil penelitian, teori komunikasi yang dipakai adalah interaksi simbolik. Penelitian kualitatif ini menggunakan metode fenomenologi. Teknik pengumpulan data dilakukan melalui wawancara mendalam dan pengamatan. Data selanjutnya dianalisis menggunakan teknik enam langkah menurut Creswell. Hasil penelitian menunjukkan bahwa mahasiswa etnis Manggarai melakukan tindakan akomodasi komunikasi sebagai solusi mengatasi penolakan sosial mahasiswa tuan rumah. Bentuk akomodasi komunikasi yang dilakukan meliputi konvergensi komunikasi dimana mahasiswa etnis Manggarai menirukan perilaku komunikasi mahasiswa tuan rumah Kota Kupang guna memuluskan terjadinya integrasi sosial di antara mereka. Konvergensi komunikasi juga dilakukan dalam bentuk "menanggalkan" sementara jati diri dan identitas asli saat berinteraksi dengan mahasiswa tuan rumah. Hasil penelitian lainnya, mahasiswa etnis Manggarai mengonstruksi pemaknaan atas status mahasiswa perantau sebagai pejuang ilmu dan pembawa perubahan dalam masyarakat dan keluarga di kampung halaman.
\end{abstract}

Kata-kata Kunci: Akomodasi; pengalaman komunikasi; makna; konvergensi komunikasi; kota Kupang.

\section{Communication Accommodation Experience of University Students from Different Culture in Kupang City}

\begin{abstract}
Understanding and multicultural insight has not get much serious attention in college. In fact, when new university students entered college they have not been given a short course on multicultural knowledge. Therefore, various researches both in Indonesia and abroad revealed that students outside their home town and foreigners experience various obstacles of cultural adaptation. Thus, the choice of accommodation communication becomes one of the solutions to overcome intercultural communication gaps. One group of students at Nusa Cendana University who consistently consider communication accommodation action is the Manggarai students. Therefore, this research was conducted to analyze the communication accomodation experience of Manggarai students with the host students at the University of Nusa Cendana, and to map the meaning of Manggarai students as nomad students in Kupang City. Symbolic interaction theory was used in order to explain the results of the research. This qualitative research used the phenomenological method with using in-depth interviews and observations data collection techniques. Furthermore, the data were analyzed by using a six-step technique of Cresswell. The results revealed that the Manggarai students took communication accommodation to overcome the social resistance of the host student. It included communication convergence in which Manggarai ethnic students adjusted the communication behaviors of host students in order to facilitate social integration among them. Communication convergence is also found by "stripping away" their original identity during the interaction. In addition, the existence of Manggarai students as nomad was interpreted as knowledge fighter and agent of change for their community and family.
\end{abstract}

Keywords: Accommodation; communication experience; meaning; communication convergence; Kupang city.

Korespondensi: Dr. Petrus Ana Andung, M.Si. Universitas Nusa Cendana. Jl. Adisucipto, Penfui Kupang, Nusa Tenggara Timur, 85148. Email: petrusanaandung@staf.undana.ac.id

Submitted: September 2019, Accepted: October 2019, Published: October 2019

ISSN: 2548-3242 (printed), ISSN: 2549-0079 (online). Website: http://jurnal.unpad.ac.id/manajemen-komunikasi 


\section{PENDAHULUAN}

Pendidikan multikultur merupakan salah satu isu yang sangat penting ditengah kehidupan masyarakat dengan berbagai perbedaan baik ras, agama, suku, bahasa, dan perbedaan lainnya. Pentingnya pendidikan multukultur ini mengemuka dalam penelitian Rochayati (2010). Ia menyatakan, salah satu kunci untuk terciptanya proses akomodasi komunikasi dalam lingkungan keluarga yang berbeda latar belakang budaya adalah pendidikan multikultur kepada anak-anak.

Namun, ironisnya, pendidikan multikultur ini belum mendapat perhatian serius dalam jenjang pendidikan formal. Hasil penelitian Syahrul \& Arifin (2018), menggarisbawahi, bahwa di sekolah-sekolah di Kota Kupang dan atau Provinsi Nusa Tenggara Timur secara keseluruhan, pendidikan yang bernuansa multikultur masih cenderung merupakan hidden agenda atau hidden curriculum. Itu pun baru pada sekolah-sekolah tertentu. Karena itu, ketika para lulusan Sekolah Lanjutan Tingkat Atas bertemu di perguruan tinggi maka perspektif multikulturalisme mereka cenderung terbatas sebab tidak disiapkan sejak di bangku pendidikan di sekolah-sekolah.

Implikasi lebih lanjut yang terjadi adalah munculnya ketidakpastian dan keterasingan saat berinteraksi dengan sesama mahasiswa dari latar belakang budaya yang berbeda. Untuk mencapai komunikasi efektif maka aspek yang sangat dibutuhkan adalah pengetahuan antar budaya. Tanpa pengetahuan antar budaya yang baik maka potensi kegagalan berkomunikasi akan sangat terbuka lebar. Karenanya, hal penting dari perjumpaan antar budaya adalah bagaimana memahami permasalahan potensial guna menciptakan kesamaan makna dan pengertian dari para partisipan komunikasi yang terlibat di dalamnya (Muchtar, Koswara, \& Setiawan, 2016).

Perjumpaan antar budaya yang paling sering dijumpai adalah di perguruan tinggi. Perjumpaan budaya tersebut tidak sedikit yang mengalami kesalahpahaman. Sebagaimana hasil penelitan Lagu (Lagu, 2016) bahwa komunikasi antar budaya antara mahasiswa di perguruan tinggi cenderung berjalan kurang optimal. Hambatannya adalah karena masing-masing individu yang berbeda latar belakang budaya mempertahankan kebiasaan berkomunikasi mereka, salah satunya dialek khas daerah. Kondisi ini diperkuat dengan adanya perbedaan persepsi mengenai bahasa yang digunakan (Lagu, 2016).

Kondisi ini tercermin dalam penelitian Moulita (2018) yang mengemukakan, perjumpaan antara budaya di antara mahasiswa tidaklah berjalan mulus. Ditemukan banyak 
hambatan komunikasi antarbudaya selama mereka mengenyam pendidikan tinggi di luar daerah. Beberapa kendala, antara lain bahasa, stereotip, prasangka, kesalahan interpretasi nonverbal, kecenderungan untuk menghakimi, dan kecemasan yang tinggi. Salah satu solusinya adalah perlunya sikap open mindedness, toleransi, dan empati. Tanpa itu maka mahasiswa tidak akan bisa melakukan adaptasi lintas budaya dengan baik dan berhasil selama menempuh pendidikan tinggi (Moulita, 2018).

Namun, hasil penelitian Lagu dan Moulita tersebut berbeda dengan Kavit (2015) yang meneliti komunikasi antar budaya pada mahasiswa di Universitas Nusa Cendana, Kupang. Menurut Kavit mahasiswa perantau dari Pulau Flores (Daerah Manggarai) memiliki kemampuan adaptasi yang baik guna mengatasi perasaan keterasingan mereka selama kuliah di Universitas Nusa Cendana.

Oleh karena itu, penelitian ini merupakan penelitian lanjutan dari apa yang telah dilakukan Kavit yang ingin lebih jauh mendalami bagaimana pengalaman mahasiswa Manggarai dalam melakukan akomodasi komunikasi antar budaya dengan mahasiswa tuan rumah di Kupang yang berasal dari etnis Rote, Sabu, dan Kupang. Pemilihan mahasiswa asal Manggarai sebagai subjek penelitian didasari oleh pertimbangan kemampuan mereka dalam melakukan adaptasi budaya dengan mahasiswa asli Kota Kupang.

Penelitian dengan topik sejenis pernah juga dilakukan Primasari (2014), yang bertujuan untuk mengetahui strategi yang digunakan mahasiswa di luar Jabodetabek untuk mengelola kecemasan serta mengetahui level penetrasi sosial yang mereka capai. Penelitian ini adalah studi kasus kualitatif dengan menggunakan wawancara mendalam. Hasilnya menunjukkan bahwa setiap mahasiswa luar Jabodetabek menggunakan strategi interaktif dengan berkomunikasi langsung dengan mahasiswa dari dalam Jabodetabek. Strategi ini dipakai untuk mengatasi kecemasan dan ketidakpastian dalam lingkungan baru. Hasilnya juga mengungkapkan bahwa mahasiswa luar Jabodetabek dapat melakukan penetrasi sosial secara efektif.

Sementaraitu, Astuti(2017)jugamelakukan penelitian dengan topik yang sama. Ia mengkaji bagaimana proses dan kendala mahasiswa yang berbeda budaya dalam melakukan akulturasi budaya di kampus Unit Pelaksana Program Tegal Universitas Negeri Semarang (UNNES). Hasil penelitiannya menyebutkan, mahasiswa berbeda budaya di Kampus UNNES walaupun mampu hidup berdampingan dengan baik, tidak lepas dari berbagai kendala komunikasi antar budaya. Pergaulan sosial para mahasiswa tersebut, demikian kata Astuti, diperhadapkan 
pada pelbagai hambatan komunikasi di antaranya masalah perbedaan bahasa, kebiasaan dan perbedaan kebudayaan.

Penelitian pada konteks komunikasi antara budaya mahasiswa di kampus luar negeri juga pernah dilakukan dengan judul "International

\section{Student's Challenge and Adjustment to} College. Melalui hasil penelitiannya, Hsiaoping, Garza, dan Guzman (2015) menemukan bahwa mahasiswa internasional di Amerika Serikat menghadapi banyak kendala akademis. Beberapa di antaranya adalah isolasi sosial dan kendala adaptasi budaya. Kendala akademis ini tidak saja terbawa saat komunikasi dengan professor dan staf di kampus namun juga dengan teman-teman kelas mereka. Akibatnya, para mahasiswa asing ini makin terlarut dalam mengalami keterasingan secara sosial selama menempuh pendidikan tinggi di Amerika Serikat.

Hasilpenelitianyangdilakukanolehpenelitipeneliti terdahulu, lebih cenderung membahas akan persoalan interaksi. Tidak diarahkan pada bagaimana konstruksi pengalaman akomodasi komunikasi antar budaya mereka secara sadar mahasiswa saat berinteraksi dengan mahasiswa tuan rumah selama studi. Dengan demikian, penelitian ini dianggap cukup aktual untuk mengkaji pengalaman akomodasi komunikasi antara mahasiswa yang berbeda latar belakang budaya.
Karena itulah, tujuan penelitian ini adalah untuk menganalisa pengalaman komunikasi mahasiswa etnis Manggarai dalam melakukan akomodasi komunikasi dengan mahasiswa tuan rumah di Universitas Nusa Cendana, dan sekaligus untuk memetakan konstruksi pemaknaan mahasiswa Manggarai tentang status sebagai mahasiswa perantau.

Untuk membantu menjelaskan topik penelitian ini, maka digunakan teori interaksi simbolik. Secara historis, pencetus lahirnya teori interaksionisme simbolik, George Herbert Mead (Blumer, 1986) memaparkan gagasan dan konsep utama tentang interaksi simbolik ini melalui bukunya yang berjudul Mind, Self, and Society. Gagasan-gagasan Mead ini kemudian dikembangkan lebih lanjut oleh salah seorang mahasiswanya bernama Herbert Blumer. Blumerlah yang justru memerkenalkan dan mempopulerkan istilah interaksi simbolik di kalangan akademisi (Mulyana, 2013).

Adapun kesimpulan Blumer ini bertumpu pada tiga premis utama dari teori interaksi simbolik. Pertama, setiap manusia pada hakekatnya memutuskan untuk bertindak dengan berdasarkan atas hasil pemaknaan mereka atas simbol-simbol yang dijumpainya dalam kehidupannya sehari-hari. Kedua, makna yang dihasilkan itu muncul sebagai hasil dari proses interaksi sosial yang dilakukannya dengan orang lain. Ketiga, makna-makna 
tersebut kemudian dimodifikasi melalui proses interpretasi saat berlangsungnya proses interaksi sosial (Blumer, 1986).

Proses interaksi sosial manusia, demikian kata Blumer, terbagi atas dua bagian yakni interaksi simbolik dan interaksi non-simbolik. Interaksi simbolik menekankan pada tindakan orang lain yang diberi interpretasi. Sementara itu, interaksi yang non-simbolik mengacu pada proses di mana seorang individu memberi respon secara langsung terhadap tindakan orang lain tanpa memberi pemaknaan pada tindakan tersebut.

Berdasarkan pandangan-pandangan di atas, maka jelaslah bahwa interaksi simbolik menekankan pada tindakan individu yang dihasilkan dari proses pemaknaannya atas simbol-simbol di lingkungan sekitarnya. Teori interaksi simbolik menurut Blumer tersebut dapat dipahami sebagai kerangka referensi dalam memahami proses interaksi di antara individu yang satu dengan lainnya secara bersama khususnya dalam hal menciptakan dunia simbolik berdasarkan pemaknaan yang mereka berikan.

Prinsip-prinsip dasar dari teori interaksi simbolik antara lain: pertama, manusia tidak seperti hewan karena manusia dikaruniai kemampuan dalam hal berpikir menggunakan akal sehatnya. Kedua, kemampuan berpikir itu dibentuk dari hasil interaksi sosial di antara individu yang satu dengan individu lainnya. Ketiga, dalam interaksi sosial tersebut individu mempelajari makna dan simbol yang memungkinkan mereka menggunakan kemampuan berpikir tersebut. Asumsi keempat, makna dan simbol memungkinkan orang melakukan tindakan dan interaksi yang merupakan ciri khas manusia pada umumnya. Kelima, orang mampu memodifikasi atau mengubah makna dan simbol yang mereka gunakan dalam tindakan dan interaksi berdasarkan interpretasi mereka terhadap situasi yang ia hadapi. Keenam, kemampuan memodifikasi tersebut terjadi karena kemampuan mereka berinteraksi dengan diri sendiri, yang memungkinkan mereka memeriksa tahapan-tahapan tindakan, menilai kuntungan dan kerugian relatif, dan kemudian memilih salah satunya. Terakhir, jalinan pola tindakan dan interaksi ini pada gilirannya akan membentuk kelompok dan masyarakat (Ritzer, 2010).

\section{METODE PENELITIAN}

Penelitian ini berada pada paradigma interpretif karena mengganggap bahwa realitas atau fenomena yang diteliti bersifat objektif. Selain itu, subjek penelitian diasumsikan sebagai makhluk yang kreatif, dinamis, dan karena itu perilaku mereka tidak dapat diprediksi. Implikasi lanjutannya, pendekatan 
penelitian yang dianggap tepat sesuai dengan pilihan paradigma tersebut adalah pendekatan penelitian kualitatif.

Adapun metode penelitian yang digunakan adalah fenomenologi. Menurut Schutz, fenomenologi mengkaji cara individu atau seseorang dalam menyusun dan membentuk ulang alam kehidupan keseharainya (Holstein \& Gubrium, 2009).

Subjek penelitian adalah mahasiswa aktif kuliah di Universitas Nusa Cendana yang tersebar ke dalam berbagai fakultas. Pemilihan informan dilakukan menggunakan teknik bola salju (snow ball). Kriteria pemilihan informan adalah pertama, merupakan mahasiswa Universitas Nusa Cendana yang berasal dari Daerah Manggarai (perantau). Kedua, minimal telah kuliah selama satu tahun. Ketiga, ada keterwakilan jenis kelamin. Keempat, kriteria keragaman lama studi mulai dari semester ke-3 hingga semester ke-12. Berdasarkan kriteria ini maka penelitian ini telah mengumpulkan data dari 12 mahasiswa dengan menganut prinsip data jenuh.

Pengumpulan data dalam penelitian ini dilakukan dengan menggunakan teknik wawancara mendalam (in-depth interview), dan observasi partisipatif (participant observation). Wawancara mendalam terhadap informan dilakukan dengan mengacu pada panduan pertanyaan. Sementara itu, observasi terlibat dilakukan dengan menggunakan bantuan lembar observasi. Setiap lembar observasi telah ditetapkan aspek-aspek yang akan diobservasi sehingga memudahkan dalam melakukan pengamatan. Pengamatan dilakukan secara bervariasi mulai dari di dalam kelas hingga di luar kelas. Amatan di dalam kelas dilakukan guna melihat posisi duduk dan interaksi antara subjek penelitian dengan mahasiswa Kota Kupang. Sementara itu, observasi di luar kelas juga dilakukan guna mengamati bagaimana komunikasi antar budaya terjalin di antara mahasiswa etnis Manggarai dengan mahasiswa tuan rumah yang berasal dari Kota Kupang. Frekuensi pengamatan dilakukan secara berulang dan terus-menerus selama satu bulan guna mendapat data yang benar-benar bisa dipercayai.

Hasil penelitian dideskripsikan senatural mungkin menurut perspektif subjek penelitian untuk menjaga autentisitas penelitian ini. Untuk menjamin validitas data maka digunakan teknik triangulasi. Adapun jenis triangulasi data yang dipergunakan adalah triangulasi sumber dan triangulasi metode. Pada triangulasi sumber, data yang diperoleh dari informan yang satu akan dicocokkan dengan informan lainnya. Data dianggap terpercaya bilamana ada saling terkonfirmasi. Triangulasi sumber ini bermanfaat untuk menghindari informasiinformasi yang bersifat subjektif dan tidak 
mewakili realitas. Selain triangulasi sumber, juga dilakukan triangulasi metode. Data yang diperoleh dari hasil wawancara mendalam akan dicocokkan dengan data hasil observasi. Data dipercayai bila informasi yang muncul dalam wawancara mendalam ditemukan sama atau didukung oleh hasil observasi lapangan.

Seluruh data yang terkumpul dalam penelitian ini kemudian dianalisis menggunakan teknik analisis data menurut model Cresswell (2013), melalui tahapan enam langkah. Langkah pertama, mengolah dan mempersiapkan data untuk dianalisis. Pada tahap ini, semua data yang diperoleh di lapangan dicatat dan dituangkan dalam bentuk transkrip wawancara. Langkah selanjutnya, membaca keseluruhan data kemudian dilakukan reduksi data. Proses reduksi data membantu dalam memfokuskan pada data-data yang sesuai dengan topik dan tujuan penelitian. Selanjutnya, peneliti menuliskan gagasan-gagasan umum dari para informan untuk mengetahui kedalaman informasi yang sudah tersedia. Ketiga, menganalisa secara lebih detail melalui proses pemberian koding. Pengkodingan dilakukan berdasarkan topik penelitian. Pemberian koding ini juga dilakukan untuk memudahkan dalam membuat kategorisasi data. Langkah keempat, membuat tema berdasarkan hasil kategorisasi sesuai tujuan penelitian. Tema-tema induktif pada tahap ini ditentukan berdasarkan fokus penelitian. Kelima, menyajikan laporan dalam bentuk deskripsi atau narasi secara kualitatif. Langkah keenam, berupa interpretasi dan atau memaknai data hasil penelitian yang sudah tersedia (Cresswell, 2013).

Penarikan kesimpulan dilakukan dengan tetap menjaga prinsip penelitian kualitatif yang mengedepankan prinsip induktif. Pada narasi laporan penelitian, proses interpretasi data hasil penelitian selain menggunakan teori interaksi simbolik juga dikaitkan dengan hasil-hasil penelitian lain yang relevan.

\section{HASIL DAN PEMBAHASAN}

Akomodasi komunikasi dipahami sebagai kemampuan yang dimiliki seseorang untuk menyesuaikan, memodifikasi, dan atau mengatur perilaku komunikasinya saat berinteraksi dengan orang lain (Morissan, 2014). Akomodasi komunikasi memiliki kaitan erat dengan adaptasi budaya. Sebagaimana dijelaskan Kim (1988), saat seseorang berpindah ke sebuah lingkungan baru dengan budaya yang asing baginya, ia berhadapan dengan proses penyesuaian dengan lingkungan baru yang dimasukinya itu. Pada konteks seperti ini, komunikasi antar budaya hanya dapat tercipta dengan efektif ketika ada saling pengertian dan penerimaan. Karena itu, akomodasi komunikasi menjadi salah satu faktor utama yang dapat menunjang terjadinya interaksi antar budaya 
secara efektif.

Mengacu pada pandangan Kim tersebut, pada bagian selanjutnya dipaparkan akan pengalaman akomodasi komunikasi mahasiswa etnis Manggarai dalam konteks interaksi antar budaya dengan mahasiswa tuan rumah (penduduk asli) asal Kota Kupang. Hasil penelitian menemukan, tindakan akomodasi komunikasi mahasiswa etnis Manggarai ternyata tidaklah berjalan mulus. Kegagalankegagalan dan bahkan perasaan terasing kerap dialami mahasiswa Manggarai khususnya saat berada pada semester awal di Universitas Nusa Cendana.

Para informan mengakui bahwa pada awalnya mereka lebih memilih berinteraksi dengan sesama mahasiswa Manggarai karena merasa kurang percaya diri dengan perilaku komunikasi khas daerah Manggarai yang berbeda dengan mahasiswa lainnya terutama mahasiswa tuan rumah.

Sebagaimana terungkap dalam hasil wawancara informan, Maria L. Viltha (wawancara 25 Maret 2019) yang mengatakan: "Pertama kali saya ketemu dengan temanteman dari kota kupang saya tidak langsung tegur mereka. Saya amati dulu bagaimana cara mereka omong dengan teman yang lain terus bagaimana cara mereka merespon. Kadang saya jadi jengkel sendiri karena, tiba-tiba kalau mereka omong dengan kami yang dari Manggarai mereka tertawa kami punya logat. Itu yang bikin saya jadi tidak mau tegur mereka duluan. Tapi kalau ada teman dari kupang yang tegur saya duluan, saya balas dengan bahasa Indonesia dan tetap pake saya punya logat (Manggarai)".

Apa yang dialami Maria tersebut juga pernah dialami oleh mahasiswa Manggarai lainnya. Kesulitan berkomunikasi dengan mahasiswa asal Kota Kupang saat pertama kali menjadi mahasiswa baru membuat Sandri N. Nindung tidak percaya diri. Berikut kutipan wawancaranya (25 Maret 2019):

"Jujur pertama kali saya lihat mereka (mahasiswa Kota Kupang) saya rasa minder, yang paling utama itu karena bahasa terus logat kami yang beda. Untung waktu itu ada saya punya teman yang dari Manggarai juga jadi, saya kemana-mana dengan dia. Karena, kalau omong juga tidak perlu jaim pake bahasa dengan logat kupang. Tapi karena, proses belajar selama perkuliahan mengharuskan saya untuk menjalin hubungan pertemanan dengan mereka akhirnya, lama-lama saya mulai gabung dengan teman-teman yang dari kupang meskipun masih sedikit canggung."

Berkenaan dengan perasaan canggung dan bahkan perasaan keterasingan ini akan berimplikasi pada kurang efektifnya komunikasi. Efektifitas dalam komunikasi antar budaya antara orang asing dengan penduduk asli menuntut atau mensyaratkan adanya pertimbangan mindful atau berpikir dengan pertimbangan-pertimbangan seperti pengetahuan akan budaya asli tersebut. Pertinbangan-pertimbangan ini biasanya digunakan oleh orang asing dengan tujuan untuk mengurangi kesalahpahaman dalam berkomunikasi. Bila hal ini dilakukan maka 
akan menjamin terciptanya proses komunikasi mindful, yang antara lain bisa dilakukan dengan menciptakan kategori-kategori baru dari pada hanya sekadar mengklasifikasikan orang berdasarkan penilaian sederhana seperti etnis, jenis kelamin, usia, ekonomi, dan kebiasaankebiasaan mereka. Hal itu juga berarti terbuka dengan informasi dan mengakui bahwa orang lain mungkin memiliki perspektif yang berbedabeda (Griffin, 2012: 133).

Berdasarkan uraian tersebut di atas maka jelaslah bahwa ketika para Mahasiswa Manggarai ini hanya bergaul dengan sesama mahasiswa Manggarai maka dapat dikatakan bahwa mereka belum membuka diri terhadap budaya atau kategori-kategori baru dalam pergaulan mereka. Menciptakan kategori baru berarti berpindah dari klasifikasi yang luas dan umum yang telah diikuti selama bertahuntahun (Samovar, Porter, \& McDaniel, 2014). Apabila proses pergaulan sesama suku ini terus berlanjut dalam waktu yang lama maka bisa mengakibatkan kesalahpahaman dan kegagalan dalam komunikasi dengan budaya asli. Oleh karena itu, iniasitif untuk memulai pertemanan dengan proses yang mindful inilah yang kemudian diterapkan oleh para mahasiswa perantau ini guna dapat beradaptasi di lingkungan barunya.

Faktor perasaan tidak nyaman dan bahkan rasa terasing inilah yang mendorong Mahasiswa etnis Manggarai melakukan modifikasi perilaku komunikasi mereka saat berinteraksi dengan mahasiswa Kota Kupang. Dengan kata lain, kegagalan melakukan komunikasi antar budaya pada semester-semester awal kuliah, mendorong mahasiswa etnis Manggarai melakukan tindakan akomodasi komunikasi dengan mahasiswa tuan rumah asal Kota Kupang. Alasan akomodasi komunikasi dalam perspektif mahasiswa etnis Manggarai ini adalah untuk mendapatkan penerimaan sosial.

Selain itu, tuntutan melakukan akomodasi komunikasi ini dipengaruhi pula oleh perbandingan jumlah mahasiswa luar daerah dengan mahasiswa lainnya. Sebagaimana dikemukakan oleh Ursula Jebatu (Wawancara, 06 Mei 2019) sebagai berikut:

"... saya coba untuk belajar logat dan bahasa Kupang, karena komunikasi dengan teman-teman orang Kupang susah sekali kalau saya tetap pake logat Manggarai karena nanti teman-teman akan tertawa dan menjadi canggung. Apalagi di kami punya kelas kebanyakan orang Kupang, Kami yang dari daerah cuma 2 (dua) orang saja. Jadi bagaimana pun kami harus bisa menggunakan dan mengerti logat serta bahasa Kupang. Setelah saya belajar logat dan bahasa Kupang dari teman-teman kelas maupun teman kos, akhirnya sekarang saya sudah lancar pake logat dan bahasa Kupang”.

Keputusan untuk melakukan akomodasi komunikasi ini dilakukan dalam beberapa cara. Pertama, Mahasiswa etnis Manggarai berupaya untuk "melepaskan" sementara identitas diri 
sebagai orang Manggarai. Menurut informan, dalam proses interaksi sehari-hari terutama saat berkomunikasi di kampus baik dengan sesama mahasiswa asal Manggarai, mereka cenderung dan menghindari menggunakan dialek dan bahasa Daerah Manggarai. Sebaliknya, mereka lebih cenderung memilih menggunakan bahasa dan dialek Kupang. Berikut penuturan Gustafianus Velgi Hamu (Wawancara 13 Mei 2019):

"Saya mulai pakai logat dan bahasa Kupang setiap kali komunikasi baik dengan orang Kupang maupun orang Manggarai saya tetap pakai logat dan bahasa Kupang. Ini karena, awal datang itu saya tinggal dengan keluarga saya yang setiap hari omong pake dialek dan bahasa Kupang. Jadi, saya juga ikut terbiasa pake logat dan bahasa Kupang. Hal ini bagus, sehingga saya jadi cepat akrab dan punya banyak teman orang Kupang dan dari daerah lainnya. Selain itu, kalau ada tugas kelompok saya tidak kewalahan karena saya sudah mampu beradaptasi dengan teman-teman orang Kupang".

Pendapat yang sama juga disampaikan Maria Lestriana Vilta Sijung (Wawancara 25 Maret 2019) yang mengatakan bahwa ia berupaya sedapat mungkin tidak menggunakan bahasa Manggarai dengan teman-temannya dari Manggarai untuk semakin terbiasa dengan dialek Kupang. "Tiap hari saya ketemu dengan mahasiswa Kupang jadi saya mau tidak mau meninggalkan kebiasaan-kebiasaan dari daerah saya saat berinteraksi dengan orang-orang Kupang”
Perilaku akomodasi ini menjadi lebih sering dilakukan mana kala interaksi di antara mahasiswa Manggarai dan mahasiswa Kota Kupang semakin intensif. Tindakan akomodasi ini memuluskan proses adaptasi budaya mereka. Hal ini sangat nampak pada proses terbangunnya keakraban sosial. Para informan berusaha untuk mulai menyesuaikan dan mengubah perilaku komunikasinya dalam berinteraksi dengan mahasiswa tuan rumah di Kota Kupang.

Proses membangun keakraban sosial ini diakui para informan dilakukan melalui keberanian dalam mengalahkan ego mereka sebagai mahasiswa pendatang. Proses membuka diri atau komunikasi yang mindfulness mulai dipraktekkan dengan membangun pertemanan. Sebagian informan mengatakan bahwa keberanian, inisiatif atau kemauan untuk memulai komunikasi dengan mahasiswa tuan rumah menjadi modal dasar bagi untuk mampu beradaptasi dengan mahasiswa Kota Kupang.

Berikut ini penuturan salah seorang informan, Ursula L. Jebatu (wawancara 06 Mei 2019):

"Yang saya lakukan pertama kali waktu datang di Kota Kupang itu, saya coba untuk belajar logat dan bahasa Kupang, ini dikarenakan komunikasi dengan teman-teman orang kupang susah sekali kalau saya tetap pake logat Manggarai karena nanti teman-teman akan tertawa dan menjadi canggung. Apalagi di kami punya kelas kebanyakan orang kupang, kami yang dari daerah cuma 2 (dua) orang saja. Jadi bagaimana pun kami harus bisa menggunakan dan mengerti logat serta 
bahasa kupang. Setelah saya belajar logat dan bahasa Kupang dari teman-teman kelas maupun teman kos, akhirnya sekarang saya sudah lancar pake logat dan bahasa Kupang."

Pendapat senada juga disampaikan oleh informan lainnya, Fransiskus X. J. Hambu (wawancara 06 Mei 2019) yang mengatakan:

"Kalau komunikasi dengan teman-teman orang Kupang saya pake logat dan bahasa Kupang, supaya kami bisa lebih akrab dan saling mengerti. Pertama kali saya belajar logat dan bahasa Kupang itu dari kakak saya yang sudah 3 tahun kuliah di Kota Kupang dan sudah bisa beradaptasi dengan budaya dan masyarakat Kota Kupang."

Berdasarkan beberapa pendapat informan tersebut di atas dipahami bahwa membangun keakraban sosial dengan mahasiswa tuan rumah di Kota Kupang menjadi pemicu utama keputusan mahasiswa Manggarai melakukan akomodasi komunikasi. Tindakan mengubah perilaku komunikasi mereka ini pada gilirannya membuat mereka diterima oleh mahasiswa tuan rumah yang umumnya ber-etnis Rote, Sabu dan Kupang.

Fenomena ini sejalan dengan pandangan Samovar, Porter, dan McDaniel (2014) yang menegaskan bahwa ketika individu dari budaya berbeda terlibat dalam komunikasi, jelaslah bahwa bahasa aslinya tidak akan digunakan. Hal ini berarti ada proses penyesuaian atau adaptasi. Lebih lanjut, jika seseorang menggunakan bahasa sendiri dalam interaksi dengan orang yang berbeda budaya maka akan ada pertimbangan-pertimbangan yang harus dimiliki untuk mengurangi potensi kegagalan komunikasi. Dalam menggunakan dialek dan bahasa lokal, tentunya para perantau ini akan lebih banyak pertimbangan dan kewaspadaan dibandingkan saat mereka menggunakan bahasa daerah mereka sendiri. Ketika berusaha untuk memberikan arti, para mahasiswa Manggarai yang menggunakan dialek dan bahasa baru ini berkomunikasi dengan lebih hati-hati untuk menanggapi apa yang dikatakan lawan bicara mereka, bagaimana hal itu disampaikan dan bagaimana meresponnya. Tergantung dari tingkat kefasihannya, para mahasiswa perantau ini secara mental menerjemahkan pesan yang diterima ke dalam bahasa aslinya, mempersiapkan respon dalam bahasa aslinya serta secara kognitif menerjemahkan respon itu ke dalam dialek dan bahasa yang baru. Jika kosakata dalam bahasa Kupang ini terbatas maka tuntutan secara kognitif semakin besar. Kesulitan pun akan meningkat saat mahasiswa Manggarai selaku penutur bahasa baru ini tidak terbiasa dengan aksen/dialek penutur aslinya yang umumnya beretnis Rote, Sabu dan Kupang.

Upaya adaptasi yang dilakukan oleh mahasiswa Manggarai menunjukan bahwa mereka telah terlebih dahulu mengidentifikasi perbedaan-perbedaan budaya mereka dengan 
budaya tuan rumah termasuk dalam aspek komunikasi, sistem komunikasi, bahasa verbal dan nonverbal (Muchtar et al., 2016). Hal inilah yang memungkinkan penyesuaian melalui proses akomodasi komunikasi, sebagaimana ditegaskan Muchtar, Koswara, dan Setiaman (2016) bahwa ada banyak bahasa verbal dan nonverbal yang sesungguhnya bersifat universal namun wujudnya secara lokal tampak berbeda. Mahasiswa Manggarai dan mahasiswa tuan rumah dalam berkomunikasi mungkin menyampaikan maksud yang sama tetapi wujud verbal dan nonverbalnya berbeda sehingga penyesuaian komunikasi mutlak diperlukan.

Akomodasi komunikasi yang dilakukan oleh Mahasiswa Manggarai ini kemudian melahirkan terjadinya proses integrasi sosial dengan mahasiswa tuan rumah. Para informan umumnya menceritakan akan keakraban sosial sebagai hasil dari keputusan mereka melakukan akomodasi komunikasi. Sebagaimana disampaikan Maria L. V. Sijung saat wawancara yang dilakukan pada 20 Mei 2019:

"Komunikasi kami nyambung sampaisampai kalau jam istirahat atau dosen tidak masuk itu kami sering curhat seperti curhat tentang dosen, mata kuliah, sampai curhat masalah pribadi. Dengan saling curhat seperti ini kami akhirnya jadi lebih akrab."

Pengalaman serupa juga diceritakan oleh Yusta Jenita, saat wawancara yang dilakukan pada 22 Mei 2019:

"kalau ada tugas yang susah tidak bisa kami kerja sendiri atau tugas kelompok, saya biasanya ajak teman-teman orang Kupang untuk kerja sama-sama di salah satu rumah atau di kosnya saya. Ini supaya kami bisa lebih akrab apalagi kami masih semester II (dua) jadi butuh waktu untuk lebih akrab. Kalau saya ajak begitu teman-teman orang Kupang senang dan mau berpartisipasi untuk kerja sama."

Indikasi terjadinya integrasi sosial ini juga diakui informan lainnya. Para mahasiswa pria asal Manggarai mengaku mengajak mahasiswa pria tuan rumah untuk bermain game bersama. Hal ini diungkapkan Gustafianus Velgi Hamu (wawancara 13 Mei 2019):

"Sekarang itu kan lagi zamannya game PUBG dan FreeFire jadi, saya dengan teman-teman orang Kupang biasanya mabar (main bareng) di kampus. Kalau tidak biasanya kami mabar di rumah teman atau kos yang ada wi-fi. Selain itu kalau malam minggu atau ada teman yang ulang tahun kami biasanya nongkrong sama-sama di kos atau di pantai. Karena kami sering sama-sama kami akhirnya jadi akrab."

Selainpertemuanrutinyangterjadidikampus dan penyelesaian tugas bersama, keterlibatan dalam organisasi kampus juga teridentifikasi sebagai salah satu cara yang digunakan oleh para mahasiswa Manggarai dalam menjalin keakraban dengan mahasiswa tuan rumah. Beberapa organisasi yang biasa menjadi wadah interaksi dan adaptasi mahasiswa asal Manggarai adalah KMK (Keluarga Mahasiswa Katolik), HIMAPRO (Himpunan Mahasiswa Prodi), BEM (Badan Eksekutif Mahasiswa), 
dan BLM (Badan Legislatif Mahasiswa). Lebih

jelasnya, disampaikan Fransiskus X. J. Hambu

(wawancara 06 Mei 2019):

"Saya masuk dalam organisasi KMK, HIMAPRO dan BEM supaya saya bisa lebih akrab dengan mahasiswa Kota Kupang dan ini terbukti bahwa sekarang teman-teman saya banyak orang Kupang. Kami saling belajar bersama dalam organisasi tersebut."

Pengalaman ini secara jelas menunjukan bahwa tindakan akomodasi komunikasi dapat mempermudah terjadinya proses integrasi di antara mahasiswa-mahasiswa yang berbeda budaya. Apalagi mereka terikat dan tergabung ke dalam suatu organisasi kemahasiswaan.

Hasil penelitian juga menemukan bahwa salah satu bentuk akomodasi komunikasi yang dilakukan oleh mahasiswa etnis Manggarai dalam komunikasi antarbudaya dengan mahasiswa tuan rumah di Kota Kupang adalah melakukan peniruan perilaku komunikasi. Peniruan ini terutama dalam gaya berkomunikasi, cara berpakaian, gaya rambut, hingga kebiasaan sehari-hari. Sebagaimana diungkapkan Gustafianus Velgi Hamu (wawancara pada 13 Mei 2019) berikut ini:

"Saya sudah mulai menggunakan bahasa dan dialek Kupang semenjak saya semester I (satu), tidak hanya itu saya juga menirukan gaya berpakaian hingga gaya rambut seperti mahasiswa Kota Kupang. dengan berperilaku seolah-olah mahasiswa asli Kota Kupang saya jadi cepat beradaptasi dan punya banyak teman orang Kupang."

Apa yang disampaikan Hamu tersebut juga dibenarkan oleh informan lainnya. Ursula L.

Jebatu dalam wawancara yang dilakukan pada 06 Mei 2019 mengaku:

"Sekarang saya sudah seperti warga asli Kota Kupang. Baik di dalam atau di luar kelas saya selalu pake dialek dan bahasa Kupang. Saya juga meniru kebiasaan mahasiswa Kupang, kalau bersalaman selalumencium hidung. Dengan berperilaku seperti warga Kupang saya dapat diterima oleh teman-teman saya yang berasal dari Kota Kupang."

Pilihan mahasiswa etnis Manggarai untuk meniru perilaku komunikasi mahasiswa tuan rumah yang berasal dari etnis Rote, Sabu dan Kupang ini sejalan dengan teori akomodasi komunikasi (West \& Turner, 2008), bahwa adanya keragaman perbedaan di antara individu "memaksa" individu-individu tersebut untuk mengakomodasi orang lain dalam proses interaksi. Apalagi bila di antara mereka terjadi banyak kemiripan baik dari segi persepsi dan keyakinan, maka proses akomodasi komunikasi menjadi lebih terbuka.

Keputusan mahasiswa Manggarai mengakomodasi komunikasi dengan mahasiswa asli Kota Kupang bila dikaitkan dengan pandangan Giles maka dapat digolongan ke dalam bentuk konvergensi dan divergensi komunikasi (Morissan, 2014). Dalam konteks konvergensi, ditemukan mahasiswa perantau yang menempuh studi di fakultas tertentu dengan jumlah mahasiswa kurang dari 5 orang setiap kelas, cenderung menunjukkan perilaku 
konvergensi.

Mahasiswa-mahasiswa ini lebih banyak melakukan proses penyatuan dengan mahasiswa tuan rumah. Littlejohn dan Foss (2009) menyampaikan bahwa konvergensi banyak bermanfaat tetapi juga bisa membawa konsekuensi lain. Konvergensi memerlukan upaya besar dan hal ini bisa berakibat hilangnya jati diri asli seorang pelaku komunikasi bila dilakukan secara berlebihan. Namun konvervensi komunikasi yang dipraktekkan oleh mahasiswa etnis Manggarai ini tidak dilakukan secara berlebihan. Walaupun mencoba 'menanggalkan' kebiasaan dan atau perilaku komunikasi yang khas dari daerah asal mereka (Manggarai) namun tidak secara serta-merta menghilangkan jati diri mereka. Penanggalan ini hanya dilakukan pada saat berinteraksi atau perjumpaan secara tatap muka dengan mahasiswa asli asal Kota Kupang.

Sementara itu praktek divergensi juga ditemukan sebagai fenomenamenarik khususnya di beberapa program studi di Universitas Nusa Cendana dengan jumlah mahasiswa sesama etnis Manggarai lebih dari lima orang pada setiap kelas. Kelompok mahasiswa etnis Manggarai bila berjumlah lebih dari 5 orang setiap kelas, cenderung menampilkan perilaku komunikasi yang cenderung ekslusif dan cenderung kurang berbaur secara maksimal dengan mahasiswa tuan rumah. Mereka lebih banyak berinteraksi dengan atau antar sesama mahasiswa Manggarai dibandingkan dengan melakukan pembauran sosial dengan mahasiswa dari etnis yang berbeda. Pilihan untuk tetap berbeda dari mahasiswa lain dilakukan untuk memperkuat jati diri mereka. Littlejohn dan Foss (2009: 224) menegaskan bahwa upaya menonjolkan karakteristik cara berbicara dalam komunitas baru dilakukan untuk memunculkan simpati dari kelompok yang menerima mereka.

Apa yang ditemukan pada perilaku akomodasi komunikasi dari mahasiswa Manggarai ini menunjukkan betapa aspek pendidikan multikultur menjadi penting. Karena itu perilaku divergensi ditemukan terutama pada tahun-tahun awal perkuliahan di perguruan tinggi. Fakta ini semakin memperkuat kesimpulan bahwa pendidikan dan atau pembekalan multikultur tidak mereka dapatkan sebelumnya baik pada jenjang pendidikan formal maupun non formal di keluarga. Sebagaimana ditegaskan Dewi \& Widyowati (2017), biasanya anak baru mengenal akan pendidikan multikultur saat mengalami perjumpaan beda budaya dalam lingkungan di mana ia berada. Lingkungan yang umumnya dijadikan ajang pembelajaran nilainilai multikultural ini antara lain di lingkungan di mana sang anak berinteraksi, atau di bangku pendidikan formal.

Pilihan akomodasi komunikasi dari 
mahasiswa etnis Manggarai ini dapat pula dipahami sebagai sebuah realitas fenomenologis. Mulyana (2013) menegaskan, realitas fenomenologis dipahami sebagai sebuah proses dimana manusia memberikan pemaknaan secara sadar akan apa yang ia alami.

Hal ini berarti betapa realitas yang dialami seseorang itu merupakan dunia bagi orang yang bersangkutan.

Berdasarkan apa yang digariskan oleh Mulyana tersebut, jelaslah bahwa berbicara mengenai realitas fenomenologis, salah satu aspek yang turut mencirikannya adalah konstruksi pemaknaan secara sadar dari orang-orang yang mengalami langsung akan realitas tersebut. Pada konteks penelitian ini, realitas fenomologisnya terletak pada konstruksi pemaknaan mahasiswa perantau asal daerah Manggarai ketika menempuh studi di Universitas Nusa Cendana, Kota Kupang.

Menyandang status sebagai mahasiswa perantau dari Manggarai memiliki makna tersendiri dalam konstruksi pemikiran mahasiswa. Karena itu, pada bagian berikutnya disajikan akan konstruksipemaknaan mahasiswa akan status mereka sebagai mahasiswa perantau di Kota Kupang. Umumnya mahasiswa etnis Manggarai membangun pemahaman bahwa keberadaan mereka di Kota Kupang sebagai pejuang ilmu. Menurut mereka, meninggalkan keluarga dan kampung halaman lalu berada di ibu kota Provinsi Nusa Tenggara Timur dengan status sebagai mahasiswa di Universitas Nusa Cendana, dinilai sebagai bentuk perjuangan. Hal mana, eksistensi mereka itu dipersepsikan sebagai pejuang ilmu pengetahuan di tanah rantau.

Para informan bahkan berceritera bahwa mereka telah berkorban meninggalkan segalagalanya demi mengejar impian yang mereka cita-citakan. Berikut pendapat Sandri Narfiana Nindung saat wawancara yang dilakukan pada 27 Mei 2019:

"Saya memaknai status saya sebagai mahasiswa perantau ini yaitu, sebagai pejuang ilmu. Saya berani untuk keluar dari zona nyaman, berada jauh dari orang tua dan keluarga demi mendapatkan ilmu dalam meraih apa yang saya cita-citakan."

Konstruksi pemaknaan sebagai pejuang ini lebih jauh diposisikan sebagai penyemangat dan motivasi dalam menyelesaikan studi mereka di Kota Kupang. Sebagaimana diungkapkan oleh Fransiskus X. J. Hambu saat wawancara yang dilakukan pada 06 Mei 2019:

"Makna yang saya dapatkan dari status saya sebagai mahasiswa perantau adalah kami mahasiswa perantau ibaarat kaum akademisi yang memperjuangkan sesuatu demi tercapai impian masa depan. Ya... memperjuangkan segalanya lah. Mulai dari memperjuangkan nasib, ilmu pengetahuan, masa depan, keluarga, dan lain-lain. Meskipun kehidupan di daerah rantauan ini sangat berat, mau tidak mau saya harus tetap bertahan dan mencoba untuk beradaptasi melewati setiap cobaan hingga saya di wisuda." 
Selain sebagai pejuang ilmu, mahasiswa etnis Manggarai juga mengonstruksi pemaknaan akan status mereka sebagai mahasiswa perantau dengan sebutan pembuat perubahan. Menurut pengakuan mahasiswa Manggarai, keberadaan mereka sebagai perantau di Kota Kupang memiliki amanah yang tidak ringan.

Misi besar yang diemban guna menyelesaikan pendidikan di jenjang perguruan tinggi (Universitas Nusa Cendana) merupakan bentuk dan cara mereka dan keluarga untuk merubah nasib. Ini terutama berkenaan dengan perubahan dan perbaikan status ekonomi dan sosial dalam masyarakat. Harapannya adalah, bila kelak telah menyelesaikan pendidikan tinggi, akan menjadi entry point bagi tersedianya lapangan pekerjaan yang lebih memadai dengan balas karya yang lebih baik.

Berikut ini adalah pandangan Yusta Jenita saat wawancara yang dilakukan pada $22 \mathrm{Mei}$ 2019:

"Sebagai mahasiswa perantau di Kota Kupang saya jadi punya banyak pengalaman dan pengetahuan baru tentang budaya, dan bahasa dari masyarakat Kota Kupang ini. Bagi saya, menjadi mahasiswa perantau di Kota Kupang adalah, sebagai pembuat perubahan kepada kehidupan yang lebih baik. Saya yakin dengan status saya sebagai mahasiswa perantau ini, kelak saya bisa menjalani hidup yang lebih baik karena saya telah melewati banyak suka duka selama saya menjadi mahasiswa perantau. Selain itu juga saya telah punya banyak pengalaman serta pengetahuan yang saya dapatkan selama berada di Kota Kupang.”
Apa yang dikemukakan oleh Jenita di atas, sejalan dengan pendapat dari informan lainnya. Salah satunya adalah Maria L. V. Sijung saat wawancara pada 20 Mei 2019:

"Sebagai mahasiswa perantau saya meyakini bahwa saya mengemban misi dan amanat keluarga demi berjuang merubah nasib dan merubah kehidupan keluarga saya yang lebih baik di masa depan. Bukan hanya saya tetapi semua mahasiswa perantau kelak menjadi orang yang berguna bagi kehidupan dan daerahnya. Melalui pengetahuan yang didapatkan selama kuliah itu menjadi bekal masa depan yang lebih baik dari keluarga kita."

Berdasarkan realitas fenomenologis tersebut maka jelaslah bahwa bahasa memiliki peranan penting sebagai wadah, sarana, dan atau saluran dalam memformulasikan keberartian pengalaman sadar seseorang mengenai realitas yang ia alami tersebut (Syam, $2014: 151$ ). Karena itu, pemaknaan mereka akan realitas yang dialami turut menentukan perilaku dan atau tindakan komunikasi dalam kehidupan keseharian mereka. Dunia yang mereka maknai menunjukkan dan atau merepresentasi dunia mereka.

Manusia merupakan makhluk yang kreatif dimana selalu menafsirkan dunia dan segala isinya menjadi sesuatu yang bermakna dan berarti (Syam, 2014). Hal ini berarti, realitas yang dialami oleh manusia itu selalu dipersepsikan sebagai sesuatu yang bernilai dan bermakna bagi individu tersebut. 
Hasil penelitian ini bila didialogkan dengan perspektif teori interaksi simbolik maka dapatlah dipahami betapa simbol yang dalam hal ini dialek dan bahasa Kupang menjadi alat atau kendaraan untuk melahirkan tindakan akomodasi. Sebagaimana dalam teori interaksi simbolik, bahasa memiliki peranan yang amat penting bagi para individu dalam proses interaksi. Bahasa berfungsi sebagai kendaraan bagi individu untuk beraksi atau bertindak dan karenanya bahasa pun lebih lanjut berperan dalam membentuk terjadinya perilaku individu (Musta'in, 2010).

\section{SIMPULAN}

Berdasarkan hasil penelitian maka dapatlah ditarik beberapa kesimpulan. Pertama, alasan utama mahasiswa etnis Manggarai melakukan tindakan akomodasi komunikasi pada mahasiswa tuan rumah Kota Kupang adalah alasan penerimaan sosial. Perasaan canggung dan kegagalan berkomunikasi di awal perjumpaan secara pribadi, memacu mahasiswa etnis Manggarai untuk melakukan akomodasi komunikasi dengan mahasiswa Kota Kupang.

Kedua, dalam proses akomodasi komunikasi antar budaya, mahasiswa perantau beretnis Manggarai cenderung melakukan praktek konvergensi komunikasi dengan mahasiswa tuan rumah yang beretnis Rote, Sabu dan Kupang dengan cara membangun keakraban sosial dan menirukan perilaku komunikasi mahasiswa tuan rumah. Proses konvergensi ini nampak dalam proses interaksi di antara kedua belah pihak yang berbeda latar belakang budaya. Bahkan, dalam konteks konvergensi komunikasi ini, para mahasiswa Manggarai rela "menanggalkan" kebiasaan mereka terkait dengan perilaku komunikasi yang khas sebagai orang asli Manggarai. Namun demikian, praktek divergensi juga cenderung tidak bisa terelakkan bilamana secara kuantitas, jumlah mahasiswa Manggarai dalam satu kelas (satu angkatan) pada setiap program studi lebih dari lima orang.

Ketiga, keberadaan mahasiswa etnis Manggarai dengan status mahasiswa perantau memiliki pemaknaan tersendiri. Status mahasiswa perantau dimaknai sebagai pejuang ilmu dan pembawa perubahan dalam masyarakat dan keluarga di kampung halaman. Makna pejuang ilmu diasosiasikan dengan latar belakang keberadaan mereka yang sedang menimba ilmu di tanah rantau (Kota Kupang). Sementara itu, istilah pembawa perubahan dikonstruksi sebagai harapan dan atau citacita yang akan menyemangati mereka dalam menimba ilmu. Pembawa perubahan ini dikaitkan dengan keadaan ekonomi orang tua mahasiswa Manggarai sehingga bekal ilmu yang diperoleh di perguruan tinggi (Universitas Nusa Cendana) akan mengubah status sosial ekonomi keluarga ketika kelak memasuki dunia 
kerja.

Hasil penelitian ini memiliki implikasi teoritis, metodologis dan praktis. Secara teoritis, hasil kajian mengenai pengalaman komunikasi mahasiswa Manggarai ini memperkuat dan memperluas khazanah ilmiah pada teori akomodasi komunikasi. Secara metodologis, penelitian ini berimplikasi pada penambahan referensi bagi penelitian-penelitian pada topik yang berbeda dengan menggunakan metode fenomenologi. Sementara itu, secara praktis hasil penelitian ini bermanfaat sebagai bahan acuan bagi masyarakat umum ketika hendak melakukan interaksi/komunikasi antar budaya. Bahwa komunikasi antar budaya yang mempertimbangkan dan mengakomodasi lawan bicara akan menjamin terjadinya komunikasi antar budaya yang efektif.

Penelitian ini menghasilkan beberapa rekomendasi akademis dan praktis. Pertama, secara akademik, disarankan agar ada kajian lanjutan guna mengkaji perilaku divergensi mahasiswa perantau di lingkungan kampus menggunakan pendekatan kuantitatif. Topik divergensi ini penting untuk diteliti guna melihat sejauh mana perilaku inikemudianmemengaruhi efektifitas komunikasi antar budaya mahasiswa. Kedua, secara praktis rekomendasi dari hasil penelitian ini yakni agar pendidikan multikultur perlu diagendakan sebagai salah satu materi pembekalan bagi mahasiswa-mahasiswa baru di perguruan tinggi. Hal ini dirasa penting untuk mengatasi kesenjangan komunikasi dan pelbagai kejutan-kejutan budaya yang dialami oleh mahasiswa-mahasiswa baru saat berada di bangku pendidikan tinggi.

\section{DAFTAR PUSTAKA}

Astuti, T. (2017). Akulturasi budaya mahasiswa dalam pergaulan sosial di kampus (studi kasus pada mahasiswa PGSD UPP Tegal FIP Unnes). Jurnal Refleksi Edukatika, $8(1)$, 60-65. Retrieved from http://jurnal. umk.ac.id/index.php/RE.

Blumer, H. (1986). Symbolic interactionism perspective and method. California: University of California Press.

Cheo. (2010). Mental health and mental illness in children and youth fact sheet for parents and caregivers. Retrieved from http:// www.cheo.on.ca/uploads/13389_Mental_ Health and Illness Overview.pdf.

Cresswell, J. W. (2013). Research design: pendekatan kualitatif, kuantitatif, dan mixed. cetakan ke-3. Terjemahan Achmad Fawaid. Yogyakarta: Pustaka Pelajar.

Dewi, Y. C., \& Widyowati, W. (2017). Pembentukan identitas budaya remaja dari keluarga pernikahan beda budaya. Jurnal Manajemen Komunikasi, 1(2). https://doi. org/https://doi.org/10.24198/jmk.v1i2.

Griffin, E. (2012). A first look at communication theory. New York: McGraw-Hill.

Holstein, J. A., \& Gubrium, J. F. (2009). Fenomenologi, etnometodologi, dan praktik interpretif. In N. K. Denzin \& Y. S. Lincoln (Eds.), Handbook of Qualitative Research. Yogyakarta: Pustaka Pelajar.

Hsiao-ping, W., Garza, E., \& Guzman, M. (2015). International student's challenge 
and adjustment to college. Education Research International. https://doi.org/ https://doi.org/10.1155/2015/202753.

Kavit, A. F. (2015). Proses komunikasi pada adaptasi mahasiswa FKIP asal Manggarai dalam mengatasi cultural shock di FKIP UNDANA Kupang. Kupang: Universitas Nusa Cendana.

Kim, Y. Y. (1988). Communication and crosscultural adaptation: an integrative theory. London: Multilingual Matters.

Lagu, M. (2016). Komunikasi antarbudaya di kalangan mahasiswa etnik Papua dan Etnik Manado di Universitas Sam Ratulangi Manado. Acta Diurna V(3), 1-10.

Littlejohn, S. W., \& Foss, Ka. A. (2009). Teori komunikasi (theories of human communication) edisi 9. Jakarta: Salemba Humanika.

Morissan. (2014). Teori komunikasi. Jakarta: Kencana.

Moulita. (2018). Hambatan komunikasi antarbudaya di kalangan mahasiswa. Jurnal Interaksi, 2(1).

Muchtar, K., Koswara, I., \& Setiawan, A. (2016). Komunikasi antar budaya dalam perspektif antropologi. Jurnal Manajemen Komunikasi, 1(1), 113-124.

Mulyana, D. (2013). Metodologi penelitian kualitatif: paradigma baru ilmu komunikasi dan ilmu sosial lainnya. Bandung: Remaja Rosdakarya.
Musta'in. (2010). "Teori diri" sebuah tafsir makna simbolik (pendekatan teori dramaturgi Erving Goffman). KOMUNIKA: Jurnal Dakwah Dan Komunikasi, 4(2), 269-283.

Primasari, W. (2014). Pengelolaan kecemasan dan ketidakpastian diri dalam berkomunikasi (studi kasus mahasiswa perantau UNISMA Bekasi). Jurnal Ilmu Komunikasi, 12(1), 26-38.

Ritzer, G. (2010). Sociological theory, eighth edition. New York: McGraw-Hill.

Rochayati, C. (2010). Intercultural communication accommodation in interethnic family. The Indonesian Journal of Communication Studies (IJCS), 3(1), $43-54$

Samovar, L. A., Porter, R. E., \& McDaniel, E. R. (2014). Komunikasi lintas budaya: communication between cultures. Edisi 7. Jakarta: Salemba Humanika.

Syahrul, \& Arifin. (2018). Kebijakan pendidikan multikultural pada peserta didik non-Islam di Sekolah Muhammadiyah Kota Kupang. Jurnal Pancasila Dan Kewarganegaraan, 3(2), 1-9. https://doi.org/http://dx.doi. org/10.24269/ jpk.v3.n2.2018.

Syam, N. W. (2014). Sosiologi komunikasi. Bandung: Media Cendekia.

West, R., \& Turner, L. H. (2008). Pengantar teori komunikasi. Jakarta: Salemba Humanika. 